\title{
Surgical tactics in treatment of traumatic raptures of the diaphragm: our experience
}

\author{
M Mkrtchyan ${ }^{*}$, H Sarkavagyan, T Khachatryan, A Khanoyan, A Manukyan, A Sardaryan, H Kikoyan \\ From 23rd World Congress of the World Society of Cardio-Thoracic Surgeons \\ Split, Croatia. 12-15 September 2013
}

\section{Background}

The aim of this retrospective study was to analyze our experience with operative approach of traumatic rapture of diaphragm (TRD).

\section{Methods}

38 patients with TRD ( 34 men and 4 women ranging from 13 to 70 years) were treated in 1993-2013. 29 patients $(76 \%)$ had a left TRD and 9 patients (24\%) right TRD. Multiple-associated injures were observed in 31 patients $(82 \%)$, and isolated TRD - in 7 patients (18\%). Causes of trauma included vehicle crash for 33 patients and fall from height for 5 .

\section{Results}

TRD was diagnosed preoperatively in 32 patients $(84 \%)$ by contrast X-Ray of gastrointestinal tract, abdominal ultrasound, and CT scan of the chest and abdomen. In $6(16 \%)$ patients TRD was diagnosed during surgery. We did not use pleural centesis to avoid injury of abdominal organs. 27 patients $(71 \%)$ underwent surgery upon 1 month of trauma episode, and 13 (34\%) - after 1 month to 13 years. Right lateral thoracotomy on the 6th interspace was performed in $9(24 \%)$ patients with right TRD. In case of large raptures the diaphragm was repaired by simple interrupted suture to chest wall on 1-2 interspaces above anatomical juncture-line which allowed repairing the diaphragm out of high tension. 11 patients (29\%) with old left TRD underwent left lateral thoracotomy on the 6th interspace. In both left and right TRDs the large diaphragmatic defects were repaired by polypropylene mesh. 18 (47\%) patients with acute left TRD were treated by left lateral thoracotomy

\footnotetext{
* Correspondence: mkoarmdok@yahoo.com

Department of Thoracic Surgery, St. Grigor Lusavorich MC, Yerevan, Armenia
}

accompanied by upper-medial laparotomy (11 cases) and laparoscopy (7 cases) for better examination of abdomen and restoring lesions. We observed 3 deaths $(8 \%)-2$ from severe craniocerebral trauma and 1 from pulmonary thromboemboli.

\section{Conclusions}

Our experience showed superiority of repairing of diaphragm on 1-2 interspaces above anatomical junctureline in right TRD to avoid hypertension of sutures and accompanying thoracotomy with laparoscopy in left TRD as a rational surgical approach.

Published: 11 September 2013

\section{doi:10.1186/1749-8090-8-S1-P38}

Cite this article as: Mkrtchyan et al: Surgical tactics in treatment of traumatic raptures of the diaphragm: our experience. Journal of Cardiothoracic Surgery 2013 8(Suppl 1):P38.

Submit your next manuscript to BioMed Central and take full advantage of:

- Convenient online submission

- Thorough peer review

- No space constraints or color figure charges

- Immediate publication on acceptance

- Inclusion in PubMed, CAS, Scopus and Google Scholar

- Research which is freely available for redistribution 